\title{
Assisting Knowledge Dissemination of Postpartum Beef Cows Management using Smartphone-Based Technology
}

\author{
Sureeporn SAENGWONG ${ }^{1, *}$, Payungsuk INTAWICHA ${ }^{1}$ and \\ Phuwitsorn PHUWISARANAKOM ${ }^{2}$ \\ ${ }^{1}$ School of Agriculture and Natural Resources, University of Phayao, Phayao 56000, Thailand \\ ${ }^{2}$ School of Information and Communication Technology, University of Phayao, Phayao 56000, Thailand
}

('Corresponding author's e-mail: sureeporn.sa@up.ac.th)

Received: 16 June 2020, Revised: 2 February 2021, Accepted: 17 February 2021

\begin{abstract}
This study led to four key findings: 1) farmers' demographics and farm characteristics, 2) mobile phone usage, 3) a postpartum cow management knowledge test, and 4) the development of a Postcow mobile app as a learning tool. A total of 40 smallholder beef cattle farmers were selected for the study from October to November 2019. The results revealed that the farmers were $72.50 \%$ males, and over half of the farmers were more than 50 years of age, $57.50 \%$, with primary school level being their highest education level at $65 \%$. It was also found that $47.50 \%$ of the respondents had never searched for new knowledge from any sources about postpartum cow management. The responses indicated that all of the respondents used mobile phones with Android operation systems with access to the internet-enabled. The main reason for their use of mobile phones was to make and receive calls $(57.14 \%)$, and the most visited platform was Line $(52.50 \%)$. With regards to the downloading of any livestock apps, about $90 \%$ of the respondents had never downloaded any before. The results of the farmers' knowledge test demonstrated that the overall average score was $31.25 \%$ of questions being answered correctly. In terms of mobile app development, the main features included a farmer knowledge test, cow production cycle, after calving management practices, feeding practices, general health care practices, and cow individual records and notifications. Our findings highlighted the need for more emphasis on making farmers aware of new technology for increased farm productivity performances.
\end{abstract}

Keywords: Beef cattle, Knowledge test, Mobile app, Postpartum cow

\section{Introduction}

Beef cattle production in Thailand makes up a significant part of the farming sector, accounting for the largest proportion of livestock in the country. According to the Department of Livestock Development (2019), Thailand had an estimated 5.87 million head of beef cattle and a farmer population of 871,508 people [1]. However, there has been a considerable decrease in the numbers of beef cattle and farmers over the last few years. In particular, the number of living female beef cattle has decreased dramatically from 6.61 million head in 2008 to 4 million head in 2019, which accounts for about a $40 \%$ decrease. In northern Thailand, in provinces such as Chiang Rai, Phare, and Phayao, the number of beef cattle has also decreased. Saengwong et al. [2] reported that most of the herd sizes of beef cattle in farms in this area were defined as being of small farm size, with beef cattle of up to 5 heads. As a result of these decreasing levels of cattle, Thai producers face the problem of how to sustain beef cattle production. Therefore, the rate of cow-calf production needs to be increased to support the markets, improving the efficiency of existing beef cattle production, improving the knowledge, management practices of farmers, and encouraging their use of new technologies [3]. Improving the efficiency of cow-calf production requires knowledge and the adoption of technology that is suitable for planning and managing the heifers so that 
cows and postpartum beef cow management can play an important role in increasing a cow's productivity performance. Specific management after a cow's calving is related to nutrition programs, care, and management.

As technology advances, agricultural information has become easier to access on mobile devices. Mobile phones are one of the more important technical innovations that have reached remote rural areas and are an essential element of every aspect of human life [4]. Today, the number of smartphone users worldwide is over 3.2 billion and this is forecast to continue growing over the next few years. In Thailand, the number of smartphone users is estimated to reach 30.05 million by 2022 [5]. Mobile apps are well-known applications that are designed to perform a specific task and run-on smartphones, tablets, and other devices. Although there has been a rapid growth of mobile app development in many sectors, existing apps related to the agricultural sector are still limited by comparison; moreover, mobile phone apps for livestock farming are even less used and less available [6]. The challenges inherent in developing a successful mobile app for farmers are various. Aside from the issues concerning the needs of users, lifecycles of the mobile apps, multidisciplinary collaboration of specialists, and design features, there are also problems relating to farmers' personalities, ages, education levels, technology awareness, internet access, etc. [7-9]. Mobile phones have reduced communication gaps between farmers, government, traders, and specialists [10,11] by employing technologies that help people communicate, update, and disseminate agricultural information and by offering solutions to address problems [12,13]. Moreover, mobile phone technology has been suitable for maintaining a normal life in the time of coronavirus but has also been able to change peoples' everyday communication by way of increasing the use of digital media technology like the internet, mobile phones, apps, and social media etc. [14].

Although various studies have developed mobile apps to serve as learning tools for assisting farmers in accessing information, studies on livestock farming, especially concerning postpartum cows, are still scanty. Therefore, this study presents the following research objectives: 1) to ascertain the demographic and farm characteristics of cattle farmers in the study area, 2) to explore the mobile phone usage of the cattle farmers in the study area, 3) to evaluate the postpartum cow management knowledgebase of the cattle farmers in the study area, and 4) the development of Postcow mobile apps as a learning tool to disseminate postpartum cow management knowledge.

\section{Materials and methods}

The project was developed in 4 steps: 1) study area and farm selection; 2) questionnaires design; 3) data collection and analysis; and 4) development of Postcow mobile apps.

\section{Study area and farm selection}

This study was conducted in Phayao province, located in the upper northern part of Thailand (19 ${ }^{\circ} \mathrm{N}$; $99^{\circ} \mathrm{E}$ ). The province consists of 9 districts divided into 68 subdistricts and 632 villages with a total area of $6,335 \mathrm{~km}^{2}$ as shown in Figure 1A. Phayao has a tropical climate with an average daily temperature of $24.8^{\circ} \mathrm{C}$ and an annual rainfall level of $1,378 \mathrm{~mm}$ [15].

The farms for the study were chosen according to data from the Phayao Provincial Livestock Office (Cattle Information System; http://mct.ict.up.ac.th:10007/farmer/\#/). Data from the beef cattle farmers in Dok Kham Tai district was used, as shown in Figure 1B. In addition, Dok Kham Tai district is also the location of the Dok Kham Tai Beef Cattle Cooperative, which produces premium grade of beef. 


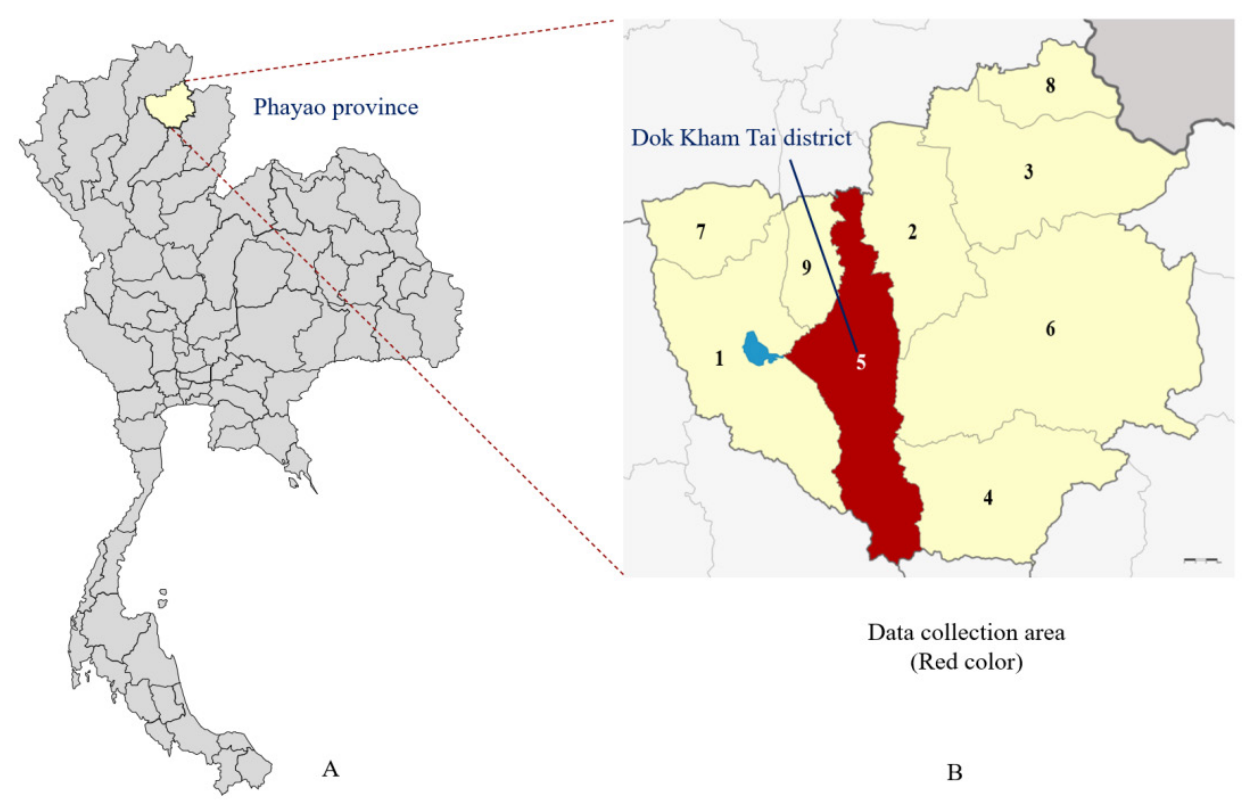

Figure 1 Map showing the location of the study site, (A) Phayao province, and (B) Dok Kham Tai district.

\section{Questionnaire design}

The questionnaire was developed which aimed at eliciting a clear understanding of the beef cattle production strategies, mobile phone usage, and postpartum cow management knowledge. The questionnaire was pre-tested before the actual data collection to check for reliability and validity by interviewing the 3 expertise and 5 farmers of the area (not part of the study sample).

The questionnaire covered various topics and was split into 4 parts:

Part 1 ascertains the demographic data of respondents including gender, age, and education level.

Part 2 explores farm characteristics, including farm experiences, rearing systems, number of beef cows, cow breeds, mating methods, the health of cows checked by livestock officers, occurrences of disease in farms, vaccination and deworming programs, and sources of postpartum management information.

Part 3 is a survey of mobile phone usage, including mobile phone operating systems, internet access, experiences of use, time spent on mobile phones per day, purposes of using, most often visited platforms, and the downloading of any app about livestock.

Part 4 is a postpartum cow management knowledge test, which, by design, covered four aspects related to postpartum cow management and consisted of basic knowledge about cow production cycles, after calving management practices, feeding practices, and general health care practices as described in Table 1. 
Table 1 Questions used on the 4 aspects of postpartum cow management.

\begin{tabular}{|c|c|}
\hline Basic knowledge about cow production cycles & $\begin{array}{l}\text { Basic knowledge about after calving management } \\
\text { practices }\end{array}$ \\
\hline $\begin{array}{l}\text { 1. At what age can a heifer be bred? } \\
\text { 2. What condition is required to inseminate a heifer? } \\
\text { 3. What are the signs of heat in cattle? } \\
\text { 4. What does anestrus mean? } \\
\text { 5. How long does a cow stay in heat? } \\
\text { 6. What is synchronized breeding? } \\
\text { 7. Length of gestation in a cow (d)? } \\
\text { 8. When should a calf be weaned? } \\
\text { 9. How long after a cow gives birth can it be bred? } \\
\text { 10. How do you determine the age of a cow? }\end{array}$ & $\begin{array}{l}\text { 1. What is the first thing to do after a cow gives birth? } \\
\text { 2. What causes a cow to die suddenly after it gives birth? } \\
\text { 3. How long does a cow have to discharge after birth? } \\
\text { 4. What are the signs of the retained placenta? } \\
\text { 5. How do you treat retained placenta in cows? } \\
\text { 6. What causes a cow to prolapse after calving? } \\
\text { 7. What are the signs of milk fever? } \\
\text { 8. What is the treatment for milk fever? } \\
\text { 9. What to do when a cow does not produce milk? } \\
\text { 10. Can a cow be bred while nursing a calf? }\end{array}$ \\
\hline Basic knowledge about feeding practices & Basic knowledge about general health care practices \\
\hline $\begin{array}{l}\text { 1. How many times should a cow be fed? } \\
\text { 2. How much feed does a cow need per day? } \\
\text { 3. How much water does a cow drink per day? } \\
\text { 4. What can be the cause of loss of appetite in cows? } \\
\text { 5. What to do when a cow has a loss of appetite? } \\
\text { 6. What is the most nutrient-rich local grass for cows? } \\
\text { 7. How much protein does a cow need per day after } \\
\text { calving? } \\
\text { 8. How much feed does a cow need to produce liter of } \\
\text { milk? } \\
\text { 9. Ideal cows condition score at calving? } \\
\text { 10. Ideal cows condition score at weaning? }\end{array}$ & $\begin{array}{l}\text { 1. How do you check a cow's health? } \\
\text { 2. How often should you check a cow's health? } \\
\text { 3. What are the signs of a healthy cow? } \\
\text { 4. What are the signs of a sick cow? } \\
\text { 5. How do you keep a cow healthy? } \\
\text { 6. How often do cows need to be dewormed? } \\
\text { 7. What is the best time to deworm cattle? } \\
\text { 8. How often should cows be vaccinated? } \\
\text { 9. Why do we vaccinate cows? } \\
\text { 10. What is the most common disease in cows after } \\
\text { calving? }\end{array}$ \\
\hline
\end{tabular}

\section{Data collection and analysis}

Data collection was conducted by experienced enumerators who were trained for this research. The survey teams used a structured questionnaire to collect information from beef cattle farmers. The target population was any person in Dok Kham Tai district who owned a cattle farm and mobile phone. Interviews were held from October to November 2019, we selected interviewees from 40 beef cattle farmers through face-to-face interviews and with the farmers' agreement, the conversations were recorded while notes were taken. Each interview took approximately $45 \mathrm{~min}$ to complete and for all the information to be collected. A datasheet was created using Microsoft Excel 2019 and questionnaire responses were manually entered. Descriptive statistics, based on frequency and percentage, were used to record demographics, farm characteristics, and mobile phone usage. For the knowledge test, descriptive statistics based on the percentage of knowledge were used.

\section{Development of learning tool (Postcow mobile app)}

Based on the evaluation of our farmers' knowledge-based tests, related to postpartum cow management, we started to create a paper mockup for specific features that the app should fulfill relating to 4 aspects of postpartum cow management and summarize the information using an infographic pattern. Following this, we have created a functional prototype that can run on a smartphone. Support for mobile phone technology for agricultural purposes on the Android-based mobile app "Postcow" was designed and developed with due consideration to the most important aspects and practices to increase the efficiency and performance of beef cow smallholder farmers. This app provides knowledge of aspects of basic knowledge about cow production cycles, after calving management practices, feeding practices, and general health care practices. In addition, we conducted regular but informal tests with the animal science students who were directly involved in beef cattle management practices. Figure 1 illustrates the main 
http://wjst.wu.ac.th

menu of the Postcow mobile app, which consists of the farmers' knowledge test, cow production cycle, after calving management practices, feeding practices, and general health care practices.

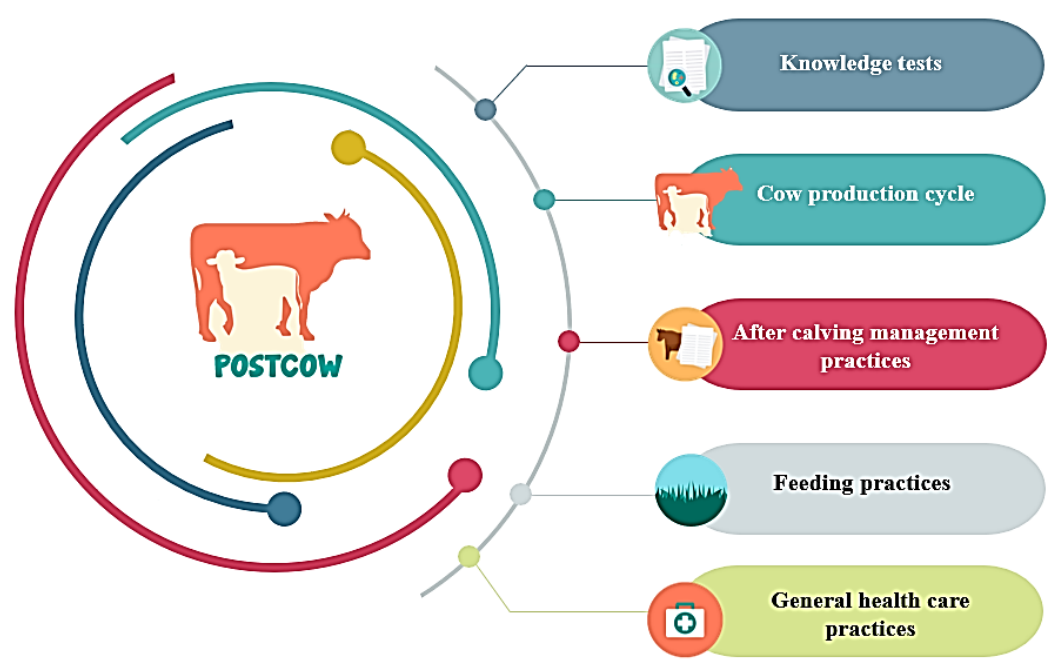

Figure 2 Main menu of the Postcow mobile app.

\section{Results and discussion}

\section{Demographic and farm characteristics}

Table 2 presents the demographic and farm characteristics of farmers recorded in the study area. The result from 40 beef cattle farmers was that over half of the respondents $(72.50 \%)$ were male. The age range of the farmers was between 51 - 60 years old, 41 - 50 years old, more than 60 years old, and 21 - 40 years old $(42.50,40.00,15.00$, and $2.50 \%$, respectively). $65.00 \%$ of the respondents had primary school level education, with only $25.00 \%$ having completed high school and just $10.00 \%$ a bachelor's degree. Regarding farming experience, only $5.00 \%$ of the respondents had 1 - 3 years of farming experience. In terms of the rearing systems used, $90.00 \%$ operated a semi-intensive system, whilst $7.50 \%$ used extensive (traditional) systems and $2.50 \%$ used an intensive method. With regards to beef cow ownership numbers, $40.00 \%$ owned up to 5 heads, $37.50 \% 6$ to 10 heads, and $22.50 \%$ over 10 heads. For breeds of cattle owned: $60.60 \%$ had Brahman crossbreeds, followed by $30.56 \%$ who had Charolais crossbreeds and $7.60 \%$ who owned the Thai native breed, and $1.24 \%$ having other breeds. Most of the respondents mated their cows using natural service, $72.50 \%$, whilst only $22.50 \%$ used AI methods. $95 \%$ of the farms had the health of the cattle checked by a livestock officer, $85 \%$ had never seen any diseases occurring on their farms and $100 \%$ of the respondents had a vaccine and deworming program in operation. About learning new knowledge about postpartum cow management, it was found that $47.50 \%$ of the respondents had never searched for new knowledge about this from any sources, $20 \%$ had learned about it from DLD officers, $17.50 \%$ from training program, and $15.00 \%$ from the internet. 
http://wjst.wu.ac.th

Table 2 Demographic and farm characteristics survey of the farmers $(n=40)$.

\begin{tabular}{|c|c|c|c|c|c|}
\hline Characteristics & $f$ & Percentage & Characteristics & $f$ & Percentage \\
\hline Gender & & & \multicolumn{3}{|l|}{ Cow breeds } \\
\hline Male & 29 & 72.50 & Brahman crossbred & 343 & 60.60 \\
\hline Female & 11 & 27.50 & Charolais crossbred & 173 & 30.56 \\
\hline Age & & & Thai native & 43 & 7.60 \\
\hline $21-40$ years & 1 & 2.50 & Others & 7 & 1.24 \\
\hline $41-50$ years & 16 & 40.00 & \multicolumn{3}{|l|}{ Mating method } \\
\hline $51-60$ years & 17 & 42.50 & AI & 9 & 22.50 \\
\hline$>60$ years & 6 & 15.00 & Natural service & 29 & 72.50 \\
\hline Education level & & & Both & 2 & 5.00 \\
\hline Primary school & 26 & 65.00 & \multicolumn{3}{|c|}{ Cow health check by livestock officer } \\
\hline High school & 10 & 25.00 & Yes & 38 & 95.00 \\
\hline Bachelor's degree & 4 & 10.00 & No & 2 & 5.00 \\
\hline Farm experiences & & & \multicolumn{3}{|c|}{ The occurrence of a disease in farm } \\
\hline $1-3$ years & 2 & 5.00 & Yes & 6 & 15.00 \\
\hline 4-6 years & 14 & 35.00 & No & 34 & 85.00 \\
\hline $7-10$ years & 11 & 27.50 & \multicolumn{3}{|c|}{ Vaccine and deworming program } \\
\hline$>10$ years & 13 & 32.50 & Yes & 40 & 100.00 \\
\hline Rearing system & & & No & 0 & 0 \\
\hline Intensive & 1 & 2.50 & \multicolumn{3}{|c|}{ I seek postpartum management knowledge from } \\
\hline Semi-intensive & 36 & 90.00 & DLD officer & 8 & 20.00 \\
\hline Extensive & 3 & 7.50 & Internet & 6 & 15.00 \\
\hline No. of beef cow & & & Training program & 7 & 17.50 \\
\hline$\leq 5$ heads & 16 & 40.00 & Not seek & 19 & 47.50 \\
\hline $6-10$ heads & 15 & 37.50 & & & \\
\hline$>10$ heads & 9 & 22.50 & & & \\
\hline
\end{tabular}

\section{Mobile phone usage}

Table 3 displays the mobile phone usage survey of beef cattle farmers, which shows that all of the respondents $(100 \%)$ used mobile phones with an Android operation system with access to the internetenabled. About $60 \%$ of the farmers had their mobile phones for 2 - 5 years. Almost half of the respondents had spent less than 1 hour per day, $40.00 \%$, using their mobile phones. A smaller percentage, $35.00 \%$, had spent 1 to 3 hours per day on their phones and even less, $25 \%$, more than 3 hours per day. The participants reported that their main purpose for using their mobile phone as follows: $57.14 \%$ said it was to make and receive calls, $17.14 \%$ for entertainment, $12.86 \%$ for educational purposes, and $12.86 \%$ to keep updated on news. The most often visited platforms were Line, Facebook, YouTube, and Google $(52.50,25.00,15.00$, and $7.50 \%$, respectively). With regards to the downloading of any livestock apps, about $90 \%$ of the respondents had never downloaded any before. 
http://wjst.wu.ac.th

Table 3 Mobile phone usage survey of beef cattle farmers $(n=40)$.

\begin{tabular}{|c|c|c|c|c|c|}
\hline Characteristics & $f$ & Percentage & Characteristics & $f$ & Percentage \\
\hline Mobile phone operatio & & & $\begin{array}{l}\text { Purposes of using mobile } \\
\text { responses) }\end{array}$ & phone & (multiple \\
\hline Android & 40 & 100.00 & To make or receive a call & 40 & 57.14 \\
\hline iOS & 0 & 0 & Educational purposes & 9 & 12.86 \\
\hline Enable internet access & & & Entertainment & 12 & 17.14 \\
\hline Yes & 40 & 100.00 & Update news & 9 & 12.86 \\
\hline No & 0 & 0 & The most often visit platform & & \\
\hline Mobile phone using & & & Facebook & 10 & 25.00 \\
\hline$<2$ years & 2 & 5.00 & Line & 21 & 52.50 \\
\hline $2-5$ years & 24 & 60.00 & Google & 3 & 7.50 \\
\hline $6-10$ years & 5 & 12.50 & Youtube & 6 & 15.00 \\
\hline$>10$ years & 9 & 22.50 & \multicolumn{3}{|c|}{ Ever download any app about livestock } \\
\hline Time spent on mobile & per & $y$ (hour) & Yes & 4 & 10.00 \\
\hline$<1$ & 16 & 40.00 & No & 36 & 90.00 \\
\hline $1-3$ & 14 & 35.00 & & & \\
\hline$>3$ & 10 & 25.00 & & & \\
\hline
\end{tabular}

\section{Evaluation of farmers' knowledge test}

The 40 multiple-choice questions on 4 aspects of knowledge were analyzed and are shown in Table 4, it is noticeable that the farmers' knowledgebase of postpartum cow management practices was basic concerning knowledge about general health care practices, feeding practices, after calving management practices, and cow production cycles $(35.50,31.00,30.00$, and $28.50 \%$, respectively).

Table 4 Evaluation of farmers' knowledge test on 4 aspects.

\begin{tabular}{lcc}
\hline Different aspects of postpartum cow management & Knowledge score average (\%) & Rank \\
\hline 1. Basic knowledge about cow production cycles & $28.50 \%$ & 4 \\
2. Basic knowledge about after calving management practices & $30.00 \%$ & 3 \\
3. Basic knowledge about feeding practices & $31.00 \%$ & 2 \\
4. Basic knowledge about general health care practices & $35.50 \%$ & 1 \\
\hline Overall average & $\mathbf{3 1 . 2 5 \%}$ & \\
\hline
\end{tabular}

Postcow mobile app user interface

The researchers produced an online-offline Android-based app that can serve as a learning tool for postpartum cow management knowledge for smallholder farmers to help them improve their knowledge and farm performance. The Postcow Android app can be downloaded from the Play Store or Google Play. The following search terms were employed "Postcow". The Postcow app was designed to enable farmers to gain knowledge about cow management practices and consists of 6 menus: cow production cycle menu, after calving management practices menu, feeding practices menu, general health care practices menu, cow individual records menu, and notifications menu (Figures 3A - 3C). Installable of application to accommodate farmers with a diverse range of mobile devices. Before using the learning tools, farmers need to test their knowledgebase level for the benefit of future development of the app and add more information that users might need. 


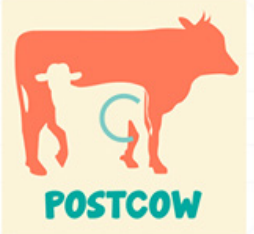

A

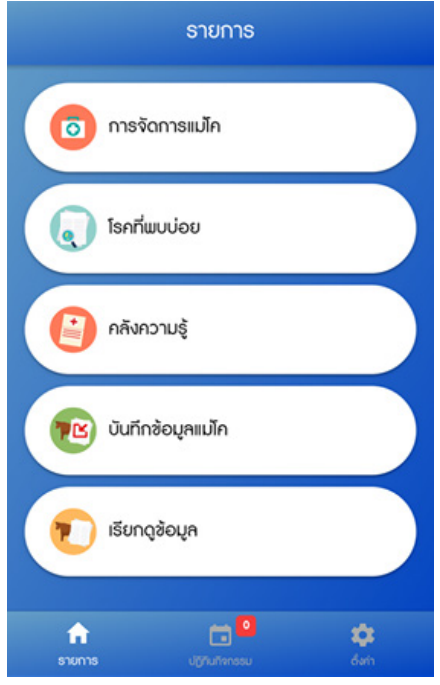

B

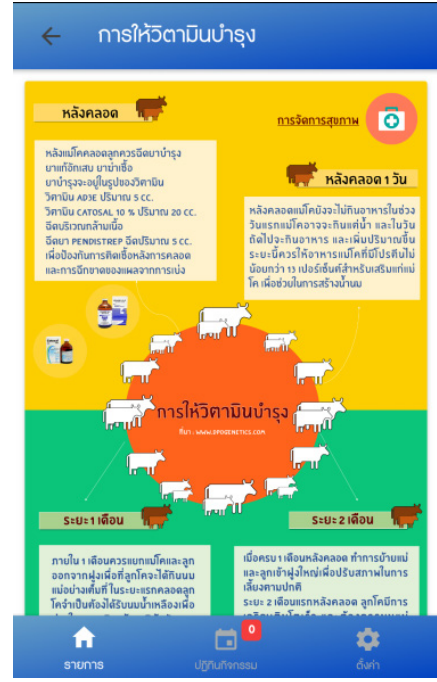

$\mathrm{C}$

Figure 3 Screenshots of the Postcow app: (A) flash page, (B) the main screen of the app, and (C) cow health care information.

\section{Discussion}

\section{Demographic and farm characteristics}

Beef cattle production is one of the major livestock activities in Thailand because it plays an important role as a source of income and job creation for smallholder farmers. With almost 6 million head of cattle, the beef cattle sector in Thailand consists of 871,508 farmers [1]. Understanding the characteristics of beef cattle farms is necessary for improving the livelihoods of farmers. The results of this study confirmed the results of earlier research, which pointed to male dominance in the beef cattle farming industry. It further revealed that the majority of these farmers are middle-aged and educated mainly to primary school level [16-19]. The experience of raising cattle can be related positively to increases in farm size because farmers gaining more experience had more knowledge and skills available for solving problems on their farms [20,21]. Three rearing systems have been identified, with the semiintensive system being the most prevalent, followed by extensive and, lastly, intensive. Smallholder farmers in Indonesia usually own 1 - 3 cows on average in their herds, which is similar to the results of this survey that showed farmers owning less than or equal to 5 cows on average [22].

One of the reproductive targets for a beef cow herd is a 365-day calving to calving interval; to achieve this, the AI technique is necessary. The key to success using AI involves the quick detection of cows that are ready to be bred and the insemination of them at the correct times [23]. Both AI and natural service are practiced as methods of breeding. Smallholder cattle farmers have been found to usually use the natural mating method, approximately $80 \%$ because they lack the skills of artificial insemination technicians and because of the high cost of the AI method [24,25].

Almost all respondents report good access to cow health checks by livestock officers, this is in line with the findings of D'Andre et al. [26], who found that the majority of cattle farmers in Rwanda claimed to have had adequate access to veterinary services.

Half of the respondents in this study area had never sort any information about postpartum management, whilst the other half had gained postpartum management knowledge from extension officers, training programs, and the internet. This finding is in line with that found by Ajwang and Onyango [27], who reported that the existing tools for accessing agricultural information where as follows: extension officers $78 \%$, mobile phones $16 \%$, and others (TV, radio, and newspapers) $4 \%$, and laptops $2 \%$, respectively. 


\section{Mobile phone usage}

Many studies about farmers' perceptions of the use of ICT in developing countries have concluded that mobile phones are one of the most important modern technologies in widespread use for the dissemination of information about agriculture production techniques, which are delivered through the internet [28-31]. In recent years, the internet has grown tremendously, making the world smaller by increasing opportunities for communities, and becoming one of the most important sources for finding information [32]. In 2018, over two-thirds of the population in Thailand had access to the internet and 90 $\%$ used the internet every day [33,34]. The agricultural and livestock sectors are no exception to this, Evans [35] concluded that mobile phones and the internet play important roles in agricultural development by providing pathways to access agricultural information for increasing farm productivity among smallholders in Africa. The observed farmers in this study were shown to all have access to the internet and have a tool that can be used to obtain information regarding agricultural practices. Based on the period of mobile phone usage, more than half had been using mobile phones for 2 - 5 years. This finding revealed that farmers had increased the period of adoption over the years; this might be related to the reduction in costs of mobile phones and internet usage, meaning that farmers are now able to afford them. The results about the main purposes for using mobile phones reveal that people not only use them to make or receive calls but also for entertainment and educational purposes. This is supported by the findings in a previous study by Dharanipriya and Karthikeyan [36] who reported that the use main function of smartphone use for farmers was for calls, social media, and the seeking of information related to agriculture, respectively.

The most often visited platforms were found to be Line, followed by Facebook, Youtube, and Google, respectively. The Line mobile app is one of the most popular social media platforms in Thailand, Japan, Taiwan, and Indonesia. Its main function is to help people chat with each other by using text messages, video calls, and group chat. In Thailand, it is estimated that $93 \%$ of mobile users have registered for the app, which is more than having done so for Facebook, at about $80 \%$ of connected users [37]. Our results show that a few of the farmers have downloaded apps related to livestock farming. This follows Michels et al. [4] who, in a study about farmers in Germany, revealed that half of the survey respondents used apps for agricultural purposes and that most were smartphone apps available for helping with plant production, with only a few for animal production.

\section{Evaluation of farmers' knowledge test}

The ability of good farm management is the key success factor for beef cattle production. General health care practice was ranked first, followed by feeding practices, after calving management practices and cow production cycles. The overall average score shows that the smallholder farmers answered only $31.25 \%$ of the questions correctly. This indicates that the knowledgebase of farmers is still limited; the results may show that farmers will achieve only low-performance rates. It is necessary to understand the farmers' knowledge backgrounds before creating learning tools. Therefore, a focus on improving the knowledge base of farmers should be one of the major target areas for any training program. By employing advancements in mobile technology and internet alternatives for self-learning, learners may obtain materials anywhere and anytime [38,39].

\section{Strengths and limitations}

Thailand has been faced with disruptive technology and innovation, especially in the agriculture sectors. To achieve readiness for the changes, the Thai government has tried to push farmers to become smart farmers through the use of advanced innovations and technologies, as we have seen from the national strategy 2018 - 2037 [40]. The results of this study demonstrate that farmers can use mobile phones and can access the internet; this indicates that there is great potential for transferring technology for long-term and expansive efforts. Mobile technology makes it possible for us to convey useful information for farmers with no limitations being posed by their lack of education. No innovation is without its drawbacks however, thus one of the limitations is as follows: despite farmers having the ability to connect to the internet, in reality, specific information sources that meet the farmers' focus area needs are still inadequate. Therefore, it is necessary to accelerate knowledge development and then 
promote access to these sources of information; the important thing is to promote self-learning. Successful delivery of new knowledge to farmers depends on many factors, as follows: the constraints of network connectivity, the information provided, farmers' capacity to use new technologies, age, gender, income, education level, and environment $[8,41,42]$. In addition, extension offices' attitudes towards new technologies will be a key element in the success of teaching and transferring information to farmers. Encouraging and training extension workers to have ICTs proficiency will be relative to the success of farmers' acceptance of these technologies $[43,44]$. Lastly, there is also a need to have a team that can update people with the best agricultural practices for developing content for the system.

\section{Conclusions}

The benefits of this mobile app include improving the ability of farmers to access and sourcing agricultural information and assisting extension officers by providing information that is different from traditional approaches. This revolution in mobile technology has made access to information easy and cost-effective. To improve the profitability of beef cattle production, farmers should be educated about suitable cow management practices and about how important it is for them to employ the benefits of modern technology. Moreover, farmers should be encouraged to increase cow management knowledge so they can increase cow productivity. The Postcow mobile app will enable farmers to get access to information on postpartum care and management. We believe that the Postcow mobile app will be useful for those running small farms because it can offer support for making decisions on farming operations. In addition, government extension offices (livestock authorities), universities, or those in the private sector should be able to increase awareness of ICTs and integrate such technologies for use within government extension programs. The sustainable way to use this platform is to promote widespread adoption by large numbers of users.

\section{Acknowledgement}

We would like to thank the Area-Based Collaborative Research (ABC61A01) for the financial support they provided us for conducting this research. We are grateful to all participants for their valuable responses and kind help.

\section{References}

[1] Department of livestock development. Number of livestock inventory (in Thai). Available at: http://ict.dld.go.th/webnew/index.php/th/service-ict/report/323-report-thailandlivestock/reportservey 2562/1372-2562-prov, accessed March 2020.

[2] S Saengwong, T Wiranut, J Wichapon and P Intawicha. The study of rearing conditions, constraints and opportunities assessment of quality beef cattle production in Phrae Province (in Thai). King Mongkut's Agric. J. 2020; 38, 254-62.

[3] M Osothongs, J Khemsawat, M Sarakul, D Jattawa, T Suwanasopee and S Koonawootrittriron. Current situation of beef industry in Thailand. In: Proceedings of the International Symposium in Dairy cattle beef up beef industry in Asia: Improving productivity and environmental sustainability, Thailand. 2016, p. 5-8.

[4] M Michels, W Fecke, JH Feil, O Musshoff, J Pigisch and S Krone. Smartphone adoption and use in agriculture: empirical evidence from Germany. Precis. Agric. 2020; 21, 403-25.

[5] Statista. Number of smartphone users worldwide from 2016 to 2021 (in billions). Available at: https://www.statista.com/statistics/330695/number-of-smartphone-users-worldwide, accessed 17 March 2020.

[6] C Costopoulou, M Ntaliani and S Karetsos. Studying mobile apps for agriculture. IOSR J. Mob. Comput. Appl. 2016; 3, 44-9.

[7] O Mapiye, G Makombe, C Mapiye and K Dzama. Management information sources and communication strategies for commercially oriented smallholder beef cattle producers in Limpopo province, South Africa. Outlook Agr. 2019; 49, 1-7. 
http://wjst.wu.ac.th

[8] J Xin, FS Zazueta, P vergot, X Mao, N Kooram and Y Yang. Delivering knowledge and solutions at your fingertips: strategy for mobile app development in agriculture. Agric. Eng. Int. CIGR J. 2015; SI, $317-25$.

[9] A Adams, R Omari and KR Teng-Viel. Smartphone usage in the greater Accra Region of Ghana: What are the critical drivers? Int. J. Asian Soc. Sci. 2020; 10, 129-41.

[10] AR Chhachhar, HB Makhijani, GM Khushk and ZA Maher. Information communication technology for agriculture development. J. Am. Sci. 2013; 9, 83-88.

[11] AR Chhachhar, B Qureshi, GM Khushk and S Ahmed. Impact of information and communication technologies in agriculture development. J. Basic. Sci. Res. 2014; 4, 281-8.

[12] NA Khan, G Qijie, S Ali, B Shahbaz and AA Shah. Farmers use of mobile phone for accessing agricultural information in Pakistan: A case of Punjab province. Cienc. Rural. 2019; 49, 1-12.

[13] Kamal. Farmers' Knowledge of ICT Interventions in Indian Agriculture Sector. 2020.

[14] C Fuchs. Everyday life and everyday communication in coronavirus capitalism. tripleC: Communication, Capitalism \& Critique. Open Access J. Glob. Sustain. Inform. Soc. 2020; 18, 37599.

[15] Climate-data. Available at: https://en.climatedata.org/asia/thailand/phayao province/phayao-4206, accessed March 2020.

[16] DV Dung, H Roubík, LD Ngoan, LD Phung and NX Ba. Characterization of smallholder beef cattle production system in central Vietnam-revealing performance, trends, constraints, and future development. Trop. Anim. Sci. J. 2019; 42, 253-60.

[17] R Widiati and TSM Widi. Production systems and income generation from the smallholder beef cattle farming in Yogyakarta Province, Indonesia. Anim. Prod. 2016; 18, 51-8.

[18] C Lambertz, C Chaikong, J Maxa, E Schlecht and M Gauly. Characteristics, socioeconomic benefits and household livelihoods of beef buffalo and beef cattle farming in Northeast Thailand. J. Agr. Rural Dev. Trop. 2012; 113, 155-64.

[19] T Suppadit, N Phumkokrak and P Poungsuk. Adoption of good agricultural practices for beef cattle farming of beef cattle-raising farmers in Tambon Hindard, Dan Khunthod distrct, Nakhon Ratchasina province, Thailand. KMITL Sci. Tech. J. 2006; 6, 67-73.

[20] M Sugiarto, S Nur, OE Djatmiko and A Einstein. Factors determining the farmer's decision to develop their beef cattle farming in the Southern Coastal Areas of Central Java. IOP Conf. Earth Environ. Sci. 2019; 255, 1-7.

[21] W Krasachat. Livestock production systems and technical inefficiency of feedlot cattle farms in Thailand. Southeast Asian J. Econ. 2008; 20, 141-54.

[22] LS Kalangi, Y Syaukat, SU Kuntjoro and A Priyanti. The characteristics of cattle farmer households and the income of cattle farming businesses in East Java. J. Agric. Vet. Sci. 2014; 7, 29-34.

[23] MG Diskin and DA Kenny. Optimising reproductive performance of beef cows and replacement heifers. Animal 2014; 8, 27-39.

[24] A Na-Chiangmai. Current situation and development trends of beef production in Thailand. In: Proceedings of the Australian Centre for International Agriculture Research. Thailand, 2001, p. 937.

[25] M Sugiarto, YN Wakhidati, A Einstein and DM Saleh. The influence of artificial insemination (AI) cost to profitability of beef cattle farming in Banjarnegara district, Central Java province, Indonesia. IOP Conf. Earth Environ. Sci. 2019; 247, 1-6.

[26] HC D'Andre, E Cyprian, M Jules, M Mupenzi, N Felix and WP Amponsah. Livestock farming and management: The case of meat production and processing in Rwanda Asian J. Anim. Sci. 2017; 11, 96-107.

[27] OS Ajwang and AJ Onyango. Evaluation of existing architecture for M-Mining market access information among sugarcane farmers in Migori County, Kenya. J. Comput. Sci. Telecommun. $2017 ; 8,1-5$.

[28] F Aldosari, MS Al Shunaifi, MA Ullah, M Muddassir and MA Noor. Farmers' perceptions regarding the use of Information and Communication Technology (ICT) in Khyber Pakhtunkhwa, Northern Pakistan. J. Saudi Soc. Agric. Sci. 2017; 18, $211-7$. 
http://wjst.wu.ac.th

[29] B Daniso, M Muche, B Fikadu, E Melaku and T Lemma. Assessment of rural households' mobile phone usage status for rural innovation services in Gomma Woreda, Southwest Ethiopia. Cogent Food Agric. 2020; 6, 1-13.

[30] N Dlodlo and J Kalezhi. The internet of things in agriculture for sustainable rural development. In: Proceedings of the 2015 International Conference on Emerging Trends in Networks and Computer Communications. 2015, p. 13-8.

[31] E Pangaribowo and N Gerber. Technological and Institutional Innovations for Marginalized Smallholders in Agricultural Development. In: Innovations for Food and Nutrition Security: Impacts and Trends. eBook, Springer, 2016, p. 41-64.

[32] AR Chhachhar, B Qureshi, GM Khushk and S Ahmed. Impact of information and communication technologies in agriculture development. J. Basic. Appl. Sci. 2014; 4, 281-8.

[33] NBTC. Office of The National Broadcasting and Telecommunications Commission. Available at: http://webstats.nbtc.go.th/netnbtc/INTERNETUSERS.php, accessed March 2020.

[34] Digital Thailand Report. Available at: https://www.bullvpn.com/en/blog/detail/digital-thailand-2019 Climate-data.org, accessed March 2020.

[35] E Olaniyi. Digital agriculture: Mobile phones, internet \& agricultural development in Africa. Actual Problems of Economics, 2018, p. 76-90.

[36] A Dharanipriya and C Karthikeyan. Use of smart phones by farmers as a tool for information support in agriculture. J. Krishi Vigyan 2019; 7, 251-6.

[37] K Satcharoen. Mobile phone background design for older adults: A case study of line. Int. J. Comput. Theory Eng. 2019; 11, 31-4.

[38] F Ozdamli and N Cavus. Basic elements and characteristics of mobile learning. Proc. Soc. Behav. Sci. 2011; 28, 937-42.

[39] C Sanga, M Mlozi, R Haug and S Tumbo. Mobile learning bridging the gap in agricultural extension service delivery: Experiences from Sokoine University of Agriculture, Tanzania. Int. J. Educ. Develop. ICT 2016; 12, 108-27.

[40] National Strategy Secretariat Office. National strategy 2018-2037 (summary). Available at: https://www.bic.moe.go.th/images/stories/pdf/National_Strategy_Summary.pdf, accessed March 2020.

[41] JS Tata and PE McNamara. Impact of ICT on agricultural extension services delivery: Evidence from the Catholic Relief Services SMART skills and Farmbook project in Kenya. J. Agr. Educ. Ext. 2018; 24, 89-110.

[42] GH Hoang. Adoption of mobile phone for marketing of cereals by smallholder farmers in Quang Dien District of Vietnam. J. Agric. Ext. 2020; 24, 106-17.

[43] DM Mwansa. Demystifying learning and knowledge: Extending the scope of literacy. Adult Educ. Develop. 2004; 61, 87-98.

[44] A Afzal, FS Al-Subaiee and AA Mirza. The attitudes of agricultural extension workers towards the use of e-extension for ensuring sustainability in the Kingdom of Saudi Arabia. Sustainability 2016; 8, $1-10$. 